\title{
EMU - “Optimum” or “Viable” Currency Area?
}

Iulia Andreea Bucur Ph.D, "Vasile Alecsandri” University of Bacău, Romania

\begin{abstract}
Although the increasing heterogeneity as an effect of European Union enlargement, referring especially to the last two waves, is perceived as a single internal market and also euro single currency risk, European Monetary Union represents an important step towards deepening economic integration. Controversy on the Optimum Currency Area issue has created difficulties in empirical research effort to find appropriate responses to the EMU dilemma: is Euro zone an „optimum” or rather "viable" currency area?
\end{abstract}

\section{Key-words}

European Monetary Union (EMU), Optimum Currency Area (OCA), euro zone, asymmetric shocks

JEL Code: $E 42, F 15, F 33$

\section{Introduction}

In 1999, eleven Member States of the European Union decided to give up monetary autonomy in favor of the European common currency, creating Economic and Monetary Union, which has gradually expanded, reaching now 17 Member States. From the theoretical perspective, the achievement of the EMU is based on the theory of Optimum Currency Area, reason for which, the present paper aims to analyze the ambitious and, at the same time, the risky European monetary project in the light of this theory.

Multitude of research on euro zone had OCA theory as a starting point, both in terms of individual properties ${ }^{1}$ (employment and capital, wages and prices flexibility) and in terms of meta-properties $^{2}$ - the result of individual criteria aggregation, especially synchronization of business, whose evolution after the lunch of the euro has received a special attention.

\section{A brief review of the literature on OCA theory}

Although some ideas appears Milton Friedman (1953) and James Edward Meade (1957) works, OCA theory bases are Robert Mundell (1961) studies which, moreover, introduced the concept of OCA referring to the geographical area that would benefit from a single monetary policy under a common currency and fixed exchanges rates.

Considering optimum currency area as a group of regions characterized by a sufficient mobility tendency to ensure full employment when one region is affected by a shock, Mundell (1961) analyzed in his research the conditions that can ensure a proper functioning

\footnotetext{
${ }^{1}$ See Lopez, C. and Papell, D.H. (2007), Berger, H. and Nitsch, V. (2008), Fratzscher, M., and Stracca, L. (2009), Campolmi, A. and Faia, E., (2011)

2 Mongelli, F.P. (2005), What is European Economic and Monetary Union telling us about the properties of optimum currency areas?, Journal of Common Market Studies, Volume 43, Issue 3, pp.607-635
} 
of a monetary union when EMU was in draft, sensing challenges that states wishing to participate at the monetary unification has to face with.

Mundell distinguish the basic properties that define the status of an optimum currency area: the high level of openness of the member states economies, a high mobility of labor and capital, including increased flexibility of wages and prices and, last but not least, the existence of transfers tax where tax revenues are redistributed deployed to areas in recession. All these criteria, given that economies are prone to asymmetric shocks, i.e. not affected by the business cycle synchronous.

The classical contributions of Ronald McKinnon (1963) and Peter Kenen (1969) joined Mundell's study. McKinnon considers that as a country is increasingly integrated into international trade, its economy could enjoy more benefits as a result of its membership in a currency area. Kenen argues that monetary unions would be more appropriate for countries with diversified economies, so demand or supply shocks affecting a particular sector could be more easily compensated by other sectors.

OCA issue was also approached and treated by other economists. Jeffrey Frankel and Andrew Rose (1998) argue that the optimal currency area implies the existence of a single currency and a common monetary policy, while Francesco Mongelli (2002) defines the optimal currency area as "optimal geographical area of a single currency or a group of countries which irrevocably fixed exchange rated and will unite" 3 .

In the sense of Jacques Pelkmans (2003) OCA means, in a simplistic manner, "that area for which the cost of giving up exchange rate flexibility or realignment option is lower than the benefits of a common currency" 4 .

More than half a century took place since the foundations of OCA theory, which proved to be particularly strong, were laid. Along with strengths, we have witnessed in the recent decades to the weaknesses and limitations of the analytical framework (between 1960s and mid-1970) and later, by the mid-1980s, to be pretty much ignore.

Beyond many weaknesses of OCA theory, it has its merit as a "catalyst for analysis", without which there exist a systematic control of numerous economic characteristics that define European monetary construction.

\section{“Optimum” versus "viable”}

OCA theory has evolved simultaneously with European economic integration and there are authors such as Filippo Cesarano (1985) who argued and demonstrated that what really matters in terms of a currency area is not being "optimal", but most of all "viable".

Initial research in this field belong to Mundell (1961) who was particularly concerned about whether the specific considered monetary areas (some regions of the U.S. and Canada) are preferable in comparison with the actual situation.

On the euro zone viability, numerous studies have been made mainly in the period before Treaty of EU entered into force and the detailed planning stages of EMU, but there are other studies that reach relatively uncertain conclusions. As concerns whether EMU meets the statute of an optimum currency area, the impossibility of a clear answer has led some economists to use alternative expressions such as: "viable currency area", "feasible currency area" or "advantageous currency area".

\footnotetext{
${ }^{3}$ Mongelli, F.P. (2002), ,New” Views on the Optimum Currency Area Theory: What is EMU Telling Us?, European Central Bank, Working Paper Series No.138, p.7

${ }^{4}$ Pelkmans, J. (2003), European Integration. Methods and Economic Analysis, Second Edition, European Institute of Romania, Bucharest

${ }_{5}^{5}$ Mongelli, F.P. (2008), European economic and monetary integration and the optimum currency area theory, Economic Papers, No. 302, p.8
} 
It considers that the Member States of an integrationist group can benefit from each other of a common currency possession only being a member of an optimum currency area, i.e., when their economic structures are similar and there is no risk that asymmetric shocks affecting only some of these countries. However, the economies of the euro area recorded significant differences between the levels of development, which will cause different reactions from external shocks. Asymmetric shocks can also cause certain failures from the perspective of business cycles incompatibility, some Member States may be quite in the growth phase, others in the decline or stagnation, so that a single monetary policy could not solve the problems of all countries involved ${ }^{6}$.

Economists Jacques Melitz (1995) and Michael Funke (1997) argue that it is difficult to determine the true nature of shocks and, at the same time, note that the notion of asymmetric shock acquired an exaggerated importance given that hypothesis symmetric shocks versus asymmetric shocks is not an operational one and cannot be tested directly.

Authors such as David Currie, Paul Levine and Joseph Pearlman (1996), believes that euro zone behave best towards asymmetric shocks than any other monetary regimes that could have been established in the participating countries.

Debates on this issue have evolved especially after the results of empirical research of Tamim Bayoumi and Barry Einchengreen (1997) which, by creating an index of OCA, concluded that Germany, Austria, Belgium and Netherlands were the most suitable EMU candidates, while the pairs of countries Portugal and Spain, and also Italy and Greece could have mutual benefits from monetary unification. Also, the two economists believes that there is a "block of Northern Europe" consists of Austria, Belgium, Denmark, France, Germany and Netherlands, countries that generally meet symmetric shocks, hypothesis from which the authors derived the idea of European monetary unification in "two speeds", i.e. the socalled "differentiated integration". The same conclusion reached Juergen von Hagen and M. Neuman (1994) noting that there are some distortions in exchange rate as a result of asymmetries caused by real shocks. Subsequently, Funke (1997) states that, although the idea of a "two speeds" European monetary union is questionable in terms of political, monetary unification is the only way to not postpone indefinitely the achievement of the ambitious and grand European project.

There are, however, authors who disputed the clear demarcation between "central countries" (more developed) and "peripheral countries" (less developed). As Jose Vinals (1996) demonstrated, shocks produced in the past for some countries were caused by mismanagement of national monetary policies and also by the effect of replacing the currency and exchange rate developments, and were not caused by the "central" or "peripheral" character of the states concerned".

\section{Some benefits and costs of creating EMU}

If the basic criteria of the currency area existence are not fulfilled, the costs of unification are superior to benefits and a system of flexible exchange rates between different currencies is desirable. Considering EMU a viable monetary area, there can be highlighted certain benefits and $\operatorname{costs}^{8}$ arising from its establishment in Europe.

One of the advantages of creating the euro zone is related to the necessity to complete the single market with a common currency and thus eliminate the exchange rate fluctuations, reduce risks related to trade and to investment transactions, and eliminate conversion costs

\footnotetext{
${ }^{6}$ Cerna, S. (2006), Teoria zonelor monetare optime, West University Publishing House, p.81

${ }^{7}$ Vinals, J. (1996), European monetary integration: A narrow or a wide EMU?, European Economic Review, Volume 40, Issues 3-5, pp.1103-1109

8 European Institute of Romania (2005), Uniunea Economică şi Monetară, Seria Micromonografii Politici Europene, pp.6-7
} 
and increase transfer speed of monetary flows. However, loss of control and of decisionmaking power on monetary issues is an argument against monetary unification in Europe.

Prices of goods and services transparency, the need for monetary discipline imposed by euro zone economies affecting the inflation decrease, merger financial markets that can lead to economies of scale, higher efficiency and rates of economic growth, strengthening the position of the Union within international monetary system and, last but not least, facilitating in achieving the objective to creating political union, are other advantages of creating EMU. Instead, notable differences on the business cycles and living standards between Member States could divide European Union in inside and outside euro zone member states, the material costs incurred to replace national currencies with euro, and also the institutional and legislative changes required, can be considered other costs European monetary unification.

Most EMU Member States has shown otherwise positive effect predicted by the theory, sometimes posting some delays in economic development. The fact is that, at least to date, in the case of Western European single market has not been a major obstacle to monetary unification.

Starting from the premise of the best existing solution, by identifying factors of influence in assessing whether a national economy is considered ready for monetary integration, OCA theory is actually closer to a formal model, empirical research demonstrating the relevance of criteria being insufficient. The decision on whether an economy integration in a common currency area should consider ex ante research completed by ex post ones, that takes into account the dynamic aspects of monetary integration.

\section{Final remarks}

In the frame of increasing challenges arising from EMU creation until now, EU Member economies relatively low capacity to not affect and to maintain economic balance within it leads us to consider inadequate the allocation of optimum currency area term for the euro area, while using terms viable currency area or rather functional which defines a group of countries that may join the monetary union based on minimum conditions, we consider it more appropriate to economic realities of European construction.

In the long term, we believe that monetary unification between all EU Member States is necessary and possible only in the context of increasing economic integration, with inherent risks, and also of the political will demonstrated by the history of ambitious project became a reality.

\section{References}

1. Berger, H., Nitsch, V. (2008), Zooming Out: the Trade Effect of the Euro in Historical Perspective, Journal of International Money and Finance, Volume 27, Issue 8, pp. 1244-1260;

2. Campolmi, A., Faia, E. (2011), Labor Market Institutions and Inflation Volatility in the Euro Area, Journal of Economic Dynamics and Control, Volume 35, Issue 5, pp. 793-812;

3. Cerna, S. (2006), Teoria Zonelor Monetare Optime, West University Publishing House, Timişoara;

4. Cesarano, F. (1985), On the Viability of Monetary Unions, Journal of International Economics, No. 19

5. Currie, D., Levine, D., Pearlman, J. (1996), The Choise of „Conservative” Bankers in Open Economies: Monetary Regime Options for Europe, Economic Journal, Volume 106, Issue 435, pp. 345-358;

6. Frankel, J., Rose, A. (1998), The Endogeneity of the Optimum Currency Area Criteria, The Economic Journal, Volume 108, Issue 449;

7. Fratzscher, M., Stracca, L. (2009), The Political Economy Under Monetary Union: Has the Euro Made a Difference?, Economic Policy, Volume 24, Issue 4, pp. 307-348;

8. Funke, M. (1997), The Nature of Shocks in Europe and in Germany, Economica, London School of Economics and Political Science, Volume 64, Issue 255, pp. 461-469; 
9. von Hagen, J., Neumann, M. (1994), Real Exchange Rates within and between Currency Areas: How Far Away Is EMU?, The Review of Economics and Statistics, MIT Press, Volume 76, Issue 2, pp. 236-244;

10. Kenen, P. (1969), The Theory of Optimum Currency Areas: an Eclectic View, in Mundell R.A., Swoboda, A. (eds.)., Monetary Problems in the International Economy, University of Chicago Press, Chicago, pp. 41-54;

11. Lopez, C., Papell, D.H. (2007), Convergence to Purchasing Power Parity at the Commencement of the Euro, Review of International Economics, Vol. 15, Nr. 1, pp. 1-16;

12. McKinnon, R. (1963), Optimum Currency Areas, American Economic Review, Volume 53, Issue 4, pp. 509-517;

13. Meade, J.E. (1957), The Balance of Payments Problems of a European Free Trade Area, The Economic Journal, Volume 67, pp. 379-396;

14. Melitz, J. (1995), A Suggested Reformulation of the Theory of Optimal Currency Areas, Open Economies Review, Volume 6, Issue 3, pp. 281-298;

15. Mongelli, F.P. (2002), „New” Views on the Optimum Currency Area Theory: What is EMU Telling Us?, European Central Bank, Working Paper Series No. 138;

16. Mongelli, F.P. (2008), European Economic and Monetary Integration and the Optimum Currency Area Theory, Economic Papers, No. 302;

17. Mundell, R.A. (1961), A Theory of Optimum Currency Areas, The American Economic Review, Volume 51, Issue. 4., pp. 657-665;

18. Pelkmans, J. (2003), European Integration. Methods and Economic Analysis, Second Edition, European Institute of Romania, Bucharest;

19. Vinals, J. (1996), European Monetary Integration: A Narrow or a Wide EMU?, European Economic Review, Volume 40, Issue. 3-5, pp. 1103-1109;

20. ***European Institute of Romania (2005), Uniunea Economică şi Monetară, Seria Micromonografii - Politici Europene. 